\title{
A polymorphism for phosphate uptake/ arsenate tolerance in Holcus lanatus L.: is there a correlation with edaphic or environmental factors?
}

\author{
JUDY NAYLOR*†, MARK R. MACNAIR†, EIRENE N. D. WILLIAMS $\ddagger$ \& PAUL R. \\ POULTON§ \\ $\uparrow$ Department of Biological Sciences, Hatherly Laboratories, University of Exeter, Prince of Wales Road, Exeter EX4 \\ 4PS, †Seale Hayne, Faculty of Agriculture, Food and Land Use, University of Plymouth, Newton Abbot, Devon TQ12 \\ 6NQ and \$IACR-Rothamsted, Harpenden, Hertfordshire AL5 2JQ, U.K.
}

\begin{abstract}
Arsenate tolerance in Holcus lanatus L. is achieved by suppression of the high affinity phosphate uptake system. Tolerant plants are found at high frequency on noncontaminated soils. The selective agents acting to maintain this polymorphism are not understood. Work on the Park Grass Experiment and a nationwide survey revealed no significant correlation between the frequency of tolerant individuals and environmental or edaphic characteristics of the site. The results are interpreted in light of the low availability of phosphate in soil solution.
\end{abstract}

Keywords: arsenate tolerance, Holcus lanatus L., phosphate uptake, polymorphism.

\section{Introduction}

Toxic levels of arsenic may occur in soils and waters either as a result of weathering of rocks containing arsenical ores or, more commonly, from anthropogenic origins, e.g. mining, smelting and the use of pesticides. Many species from bacteria to higher plants show tolerance to arsenate, including Holcus lanatus L. (Yorkshire fog). The mechanism of tolerance in this grass has been studied in detail (Meharg \& Macnair, 1990, 1991, 1992a,b,c; Macnair et al., 1992; Meharg et al., 1993) and is known to involve a major gene change leading to the suppression of the high affinity phosphate uptake system. Because phosphate and arsenate are chemical analogues they are taken up into the plant by the same uptake system (Asher \& Reay, 1979; Meharg \& Macnair, 1990). Although suppression of the high affinity uptake system reduces arsenate and phosphate uptake on contaminated soils allowing survival of $H$. lanatus, the presence of a high frequency (15-70 per cent) of arsenate tolerant individuals on noncontaminated sites (Meharg et al., 1993) is puzzling. Phosphate is a major plant nutrient and often limits plant

\footnotetext{
*Correspondence.
}

growth. It is relatively immobile in the soil, being bound as calcium and magnesium salts in calcareous soils or as iron and aluminium salts in acidic soils. Consequently the concentration of phosphate in soil solution is rarely greater than $0.01 \mathrm{~mol} \mathrm{~m}^{-3}$ (Bieleski, 1973), which is within the operational range of the high affinity uptake system. The suppression of this uptake system may limit phosphate acquisition by tolerant plants. There are three possible explanations for the high frequency of tolerant plants on noncontaminated soils. (1) Tolerant plants are limited to areas of high phosphate availability, where the low affinity system operates and the high affinity system would not usually be induced. However, these requirements are seldom met in nature and tolerant genotypes would therefore be expected to be rare. (2) Species adapted to infertile soils do not usually show increased rates of ion uptake (Atwell et al., 1980; Chapin, 1980, 1983; Hommels et al., 1990). Instead selection appears to have favoured increased nutrient use efficiency and changes in growth rates, thereby reducing nutrient requirements. Tolerant plants with their apparently less efficient uptake system may therefore be better adapted to areas of poor fertility. (3) Kinetic parameters may be unimportant in determining the uptake of such a poorly soluble nutrient as phosphate, as predicted by mech- 
anistic models (Nye, 1977; Silberbush \& Barber, 1983).

To investigate the maintenance of the polymorphism for As tolerance/P uptake, edaphic conditions can be studied in an attempt to relate the frequency of tolerant morphs in a population to the soil phosphate status. This paper reports two investigations with this aim; the first involves $H$. lanatus samples taken from the Park Grass Experiment at Rothamsted Experimental Station, and the second involves a nationwide survey. Lawes \& Gilbert set up the Park Grass Experiment almost 150 years ago (Lawes \& Gilbert, 1880) to study the effects of different fertilizer treatments on the yield of hay. However, since population differentiation is most likely to occur in spatially heterogeneous environments which are fairly stable in time (Levins, 1962, 1963), the experiment has also provided the ideal environment in which to study the response of plant populations to specific soil factors. In an extensive study, Davies \& Snaydon (1973a,b, 1974, 1976), Snaydon (1970) and Snaydon \& Davies $(1972,1976)$ have followed the adaptation of Anthoxanthum odoratum (sweet vernal grass) populations to changes in edaphic factors, finding that adaptive morphological and physiological differences have evolved over small distances (less than $0.1 \mathrm{~m}$ ) and within a short period of time (less than 40 years). It is therefore possible that $H$. lanatus could have similarly adapted to the ecological conditions and this paper reports an investigation into the distribution of $H$. lanatus morphs differing in their phosphate/arsenate uptake characters on the Park Grass Experiment.

The nationwide survey takes advantage of the natural variation in soil types and nutrient status in the U.K. and an attempt was made to relate the frequency of tolerant seed in a population of $H$. lanatus to the edaphic conditions of the site.

\section{Materials and methods}

\section{Park Grass Experiment, Rothamsted}

The Park Grass Experiment was started in 1856 when a long-established pasture was divided into a series of plots which have subsequently received different fertilizer and liming treatments. The management regime has remained little changed, with the herbage being cut for hay in June and a second cut (previously grazed) in SeptemberNovember. Fertilizer and liming treatments have influenced soil and plant chemical composition, botanical composition and dominance, herbage height and yield, and soil fauna, creating a mosaic environment. For further details see Warren \& Johnston (1964), Thurston (1969), Thurston et al. (1976) and Tilman et al. (1994).

Sampling was carried out on three occasions between April and June 1993 from seven subplots differing in their edaphic conditions. Plots were chosen to represent variation in levels of phosphorus, nitrogen, sodium, magnesium, potassium and liming. Approximately 100 tillers of $H$. lanatus were collected along three transects on each subplot by excision at the lowest node possible. In order to minimize the risk of sampling individuals from the same genet twice, tillers were sampled at intervals of at least $1 \mathrm{~m}$. Tillers were then rooted in 1/10th Rorison's nutrient solution (Hewitt, 1966) for 14 days before being potted on into $7.5 \mathrm{~cm}$ pots of John Innes No. 2 compost and maintained in the glasshouse for more than 12 months before being tested for tolerance to arsenate.

Tolerance testing Five unrooted tillers of each clone were exposed at the node and supported in perspex tubes in the lid of a $12 \mathrm{~L}$ container holding $10 \mathrm{~L}$ of nutrient solution of composition $0.2 \mathrm{~mol} \mathrm{\textrm {m } ^ { - 3 }}$ $\mathrm{Ca}\left(\mathrm{NO}_{3}\right)_{2}, \quad 0.2 \mathrm{~mol} \mathrm{~m} \mathrm{~m}^{-3} \mathrm{KNO}_{3}, \quad 0.1 \mathrm{~mol} \mathrm{~m}^{-3}$ $\mathrm{MgSO}_{4} .7 \mathrm{H}_{2} \mathrm{O}$. Arsenic was supplied as sodium arsenate, $\mathrm{Na}_{2} \mathrm{HAsO}_{4}$ at a concentration of $0.133 \mathrm{~mol}$ $\mathrm{m}^{-3}$. Solutions were changed after one week and root lengths measured after 14 days (Macnair et al., 1992). Clones with mean root length over $40 \mathrm{~mm}$ were scored as tolerant (with only the low affinity $\mathrm{P}$ uptake system functional) whereas those with root lengths less than $40 \mathrm{~mm}$ were classified as nontolerant (high and low affinity $\mathrm{P}$ uptake systems operational).

Soil analysis Soil data for the Park Grass plots were from samples taken in 1991 for soluble P and $\mathrm{pH}$, and in 1959 for total $\mathrm{P}$ and organic C. On both occasions soil was sampled to a depth of $23 \mathrm{~cm}$. Sixteen or more cores were bulked from each subplot. Samples were air dried and sieved $<2 \mathrm{~mm}$ prior to analysis for soluble $\mathrm{P}$ and $\mathrm{pH},<0.5 \mathrm{~mm}$ for organic $\mathrm{C}$ and $<150 \mu \mathrm{m}$ for total $\mathrm{P}$.

Soluble $\mathrm{P}$ was determined by extraction with $0.5 \mathrm{M}$ $\mathrm{NaHCO}_{3}$ at $\mathrm{pH} 8.5$ (Olsen et al., 1954). This fraction of total soil $\mathrm{P}$ is regarded as being readily available to the plant. Total $\mathrm{P}$ was measured by perchloric acid digestion (Mattingly, 1970). Where no fertilizer $\mathrm{P}$ is applied, total soil $\mathrm{P}$ is likely to have declined by 5-10 per cent since 1959; where fertilizer $P$ is added, total soil $\mathrm{P}$ will probably have increased by $300-400 \mathrm{mg} / \mathrm{kg}$. Organic matter content was determined by dichromate oxidation using a corrected 
Walkley \& Black method (Bremner \& Jenkinson, 1960). Values will have changed little since 1959 on this long-established grassland. $\mathrm{pH}$ was measured in distilled water $(1: 2.5 \mathrm{~m} / \mathrm{v}$ ratio).

\section{Nationwide survey}

Site selection and sampling procedure Advice was sought from Wildlife Trusts to identify suitable undisturbed grassland sites which had not been reseeded in living memory. Survey work was carried out between 21 July and 10 August 1994 to coincide with the presence of ripe seed. At each location a transect was taken through the site and seed collected from more than 100 flower heads that were separated by at least $1 \mathrm{~m}$. Three soil samples were taken along the transect using a soil auger to a depth of $20 \mathrm{~cm}$. These were then bulked to give one sample per site.

Tolerance testing Winnowing was carried out prior to tolerance testing. Seed was pregerminated on moist filter paper for 3 days, at which time germinating seeds with radicals of less than $1 \mathrm{~mm}$ were transferred into nutrient solution containing $0.133 \mathrm{~mol}$ $\mathrm{m}^{-3}$ arsenate solution (details as before). This ensured all seedlings were at the same stage when testing began. A layer of alkathene beads was used to float the seedlings on top of this solution in $200 \mathrm{~mL}$ polystyrene cups. Growth was allowed to continue for 7 days at which time the root lengths of at least 100 seedlings per population were measured (Macnair et al., 1992).

Soil analysis All soil samples were air dried and $2 \mathrm{~mm}$ sieved prior to analysis. Total phosphorus was determined by digestion with sulphuric acid-hydrogen peroxide (Allen, 1989) followed by colorimetric autoanalysis. Olsen's reagent (Allen, 1989) was used to determine soluble $\mathrm{P}$. $\mathrm{pH}$ was measured in a $1: 2 \mathrm{~m} / \mathrm{v}$ ratio with $0.01 \mathrm{M} \mathrm{CaCl}_{2}$ solution. Organic matter content of soils was estimated by loss on ignition in a muffle furnace at $550^{\circ} \mathrm{C}$.

Environmental variables Data on the average annual rainfall at each site was collated from the Meteorological Office Map International Standard Period, 1941-70. Average annual sunshine was taken from the O.S. Physical Map of Great Britain, using data collected over the 30-year period, 1921-50. Latitude and longitude were also recorded for each site.

\section{Results}

\section{Park Grass Experiment}

Different fertilizer and liming treatments for over 100 years on the plots have led to significantly different values for $\mathrm{pH}$, organic matter content, Olsen $\mathrm{P}$ and total soil P (Table 1). The frequency of arsenate tolerant genotypes ranged from 55.8 to 69.0 per cent (Table 1).

Table 1 Soil chemical analysis and frequency of arsenate tolerant morphs of Holcus lanatus on plots at the Park Grass Experiment

\begin{tabular}{llcccccc}
\hline & & \multicolumn{5}{c}{$\begin{array}{c}\text { Organic } \\
\text { matter } \\
\text { content }\end{array}$} \\
Plot & Fertilizer treatment & $\begin{array}{c}\text { Total P } \\
(\mathrm{mg} / \mathrm{kg})\end{array}$ & $\begin{array}{c}\text { Olsen P } \\
(\mathrm{mg} / \mathrm{kg})\end{array}$ & $\begin{array}{c}\text { (per cent) } \\
\text { (pH }\end{array}$ & $n$ & $\begin{array}{c}\text { Per cent } \\
\text { tolerant }\end{array}$ \\
\hline 3d & Control & 490 & 3 & 5.7 & 4.8 & 98 & 62.2 \\
4/1d & P & 1430 & 142 & 6.4 & 4.9 & 110 & 66.4 \\
7d & P K Na Mg & 1320 & 160 & 4.8 & 4.8 & 42 & 69.0 \\
9/2b & N2 P K Na Mg lime & 1230 & 105 & 6.9 & 5.4 & 104 & 55.8 \\
9/2d & N2 P K Na Mg & 1360 & 186 & 7.1 & 3.6 & 79 & 60.8 \\
18b & N2 K Na Mg lime & 530 & 5 & 6.5 & 5.7 & 68 & 63.2 \\
18d & N2 K Na Mg & 530 & 4 & 5.5 & 3.6 & 99 & 64.6 \\
\hline
\end{tabular}

$\mathrm{N} 2$, ammonium sulphate supplying $96 \mathrm{~kg} \mathrm{~N} / \mathrm{ha}$; $\mathrm{P}$, triple superphosphate supplying $35 \mathrm{~kg} \mathrm{P} / \mathrm{ha}$; K, potassium sulphate supplying $225 \mathrm{~kg} \mathrm{~K} / \mathrm{ha} ; \mathrm{Na}$, sodium sulphate supplying $15 \mathrm{~kg} \mathrm{Na} / \mathrm{ha} ; \mathrm{Mg}$, magnesium sulphate supplying $10 \mathrm{~kg}$ $\mathrm{Mg} / \mathrm{ha}$; lime, 1903-64 lime applied at $4 \mathrm{t} \mathrm{CaCO}_{3} /$ ha every fourth year, and from 1965 applied as necessary to raise and maintain $\mathrm{pH}$ values of 7,6 and 5 on subplots $\mathrm{a}, \mathrm{b}$ and $\mathrm{c}$, respectively. 
A Chi-squared test was performed on the frequency of tolerant individuals on the plots. The distribution of tolerant genotypes was homogeneous $\left(\chi_{6}^{2}=3.794, P>0.05\right)$, despite a 50 -fold difference in Olsen $\mathrm{P}$ and a threefold difference in total soil $\mathrm{P}$ on the plots studied.

\section{Nationwide survey}

The nationwide distribution of the polymorphism is shown in Fig. 1. Every population studied was poly-

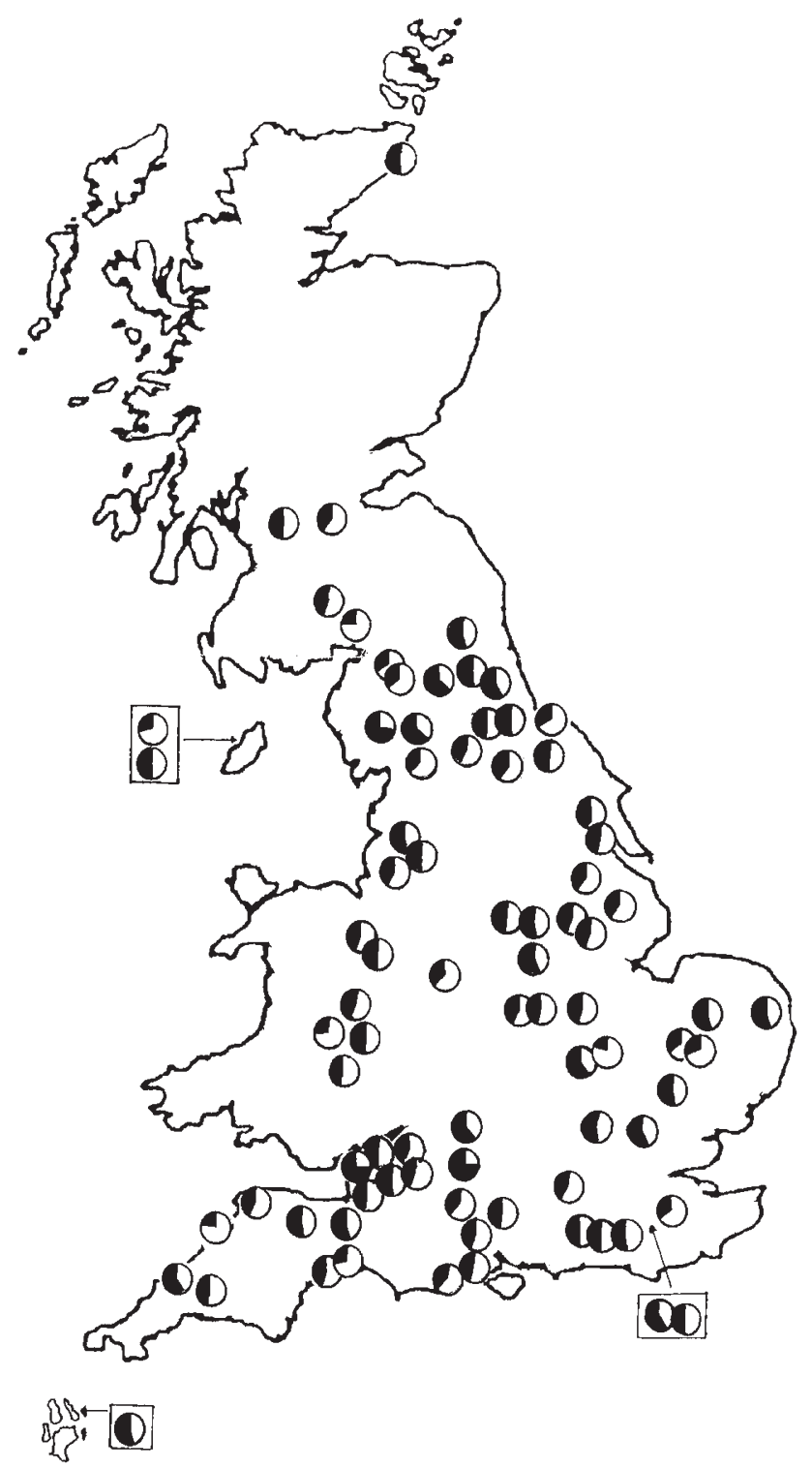

Fig. 1 The distribution of arsenate tolerant Holcus lanatus in Britain. Shaded segments represent the percentage of tolerant individuals within each population. morphic. The frequency of tolerant plants was significantly heterogeneous $\left(\chi_{84}^{2}=519, P<0.001\right)$. Table 2 gives details of each site, with data for Olsen and total $\mathrm{P}, \mathrm{pH}$ and organic matter content. Other environmental factors, rainfall, annual sunshine, latitude and longitude are also included. Correlation coefficients were calculated between the frequency of tolerant plants and edaphic and environmental variables at each site (Table 3 ). In each case there was no significant correlation between the frequency of tolerant individuals and edaphic or environmental parameters.

\section{Discussion}

\section{Park Grass Experiment}

The results presented here show no variation in the frequency of tolerant genotypes despite a 50 -fold difference in Olsen $\mathrm{P}$ and a threefold difference in total soil $\mathrm{P}$ on the plots studied. It is unlikely that the lack of variation between plots results from a lack of evolutionary time. Both $A$. odoratum and $H$. lanatus are perennial grasses which regenerate vegetatively and sexually (Watt, 1978). Yet, whereas $A$. odoratum has evolved morphological and physiological differences within 40 years on these plots (Snaydon, 1970), H. lanatus has not. Holcus lanatus flowers later than $A$. odoratum and is never allowed to set seed on Park Grass because of the timing of the herbage cuts (M. J. Crawley, personal communication). Despite this, differences would still be expected to have evolved as a result of selection operating on the vegetative stages (Hickey \& McNeilly, 1975; Davies \& Snaydon, 1976).

Another possibility is that the uniform frequency of tolerant individuals on the plots could be a result of seed rain from the surrounding area masking any evolutionary trends on the plots. This seems unlikely for a number of reasons. First, seedling establishment in a closed environment is a rare event (Weir, 1985). Secondly, the surrounding fields are cut at the same time as Park Grass leaving a very limited seed source. The frequency of tolerant progeny within this seed has been investigated and was found to be 56.4 per cent. This figure is significantly lower than the percentage of tolerant plants on the plots themselves. Therefore, it seems unlikely that seed influx is playing a major role in determining the occurrence of tolerant genotypes on the plots, and more likely that the number of tolerant genotypes has not altered in conjunction with the changing edaphic conditions of the plots. 


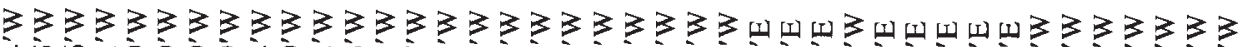

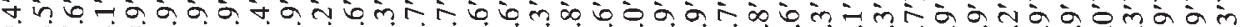

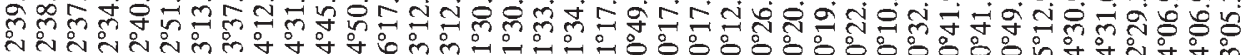

zzzzzzzzzzzzzzzzzzzzzzzzzzzzzzzzzzzzzzzz

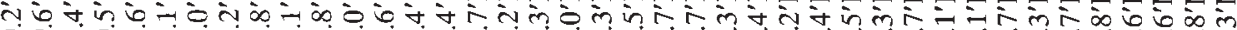

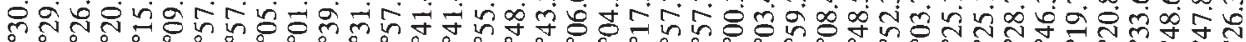

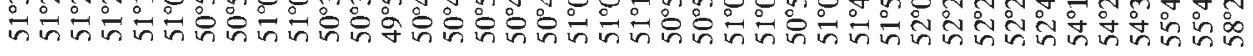

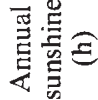

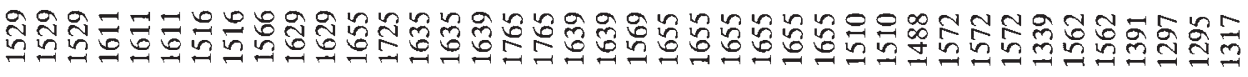

密

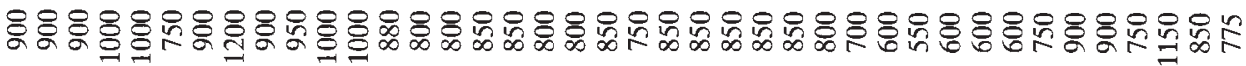

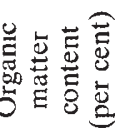

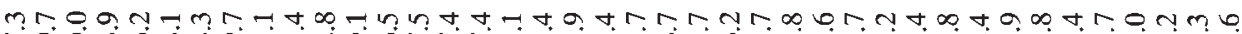

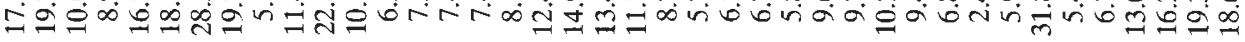

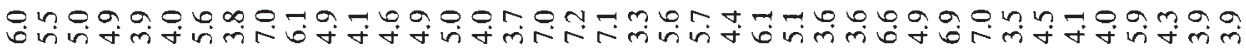

Doo-m-mNONNOt

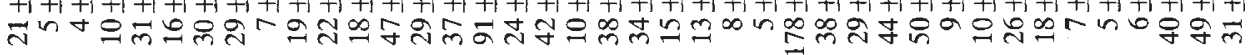

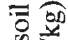

\&

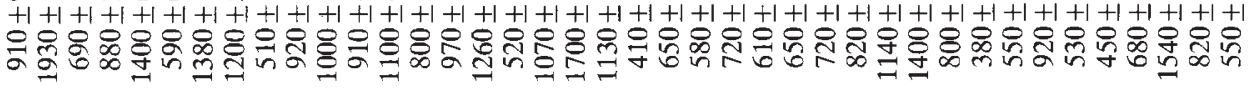

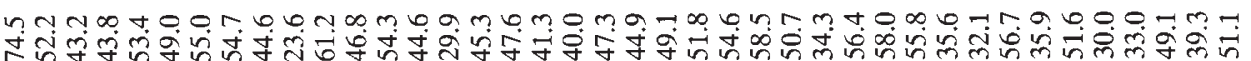

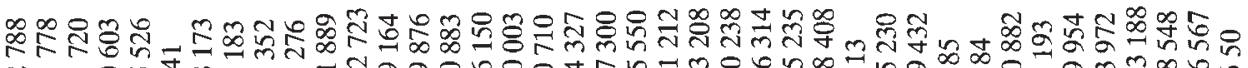

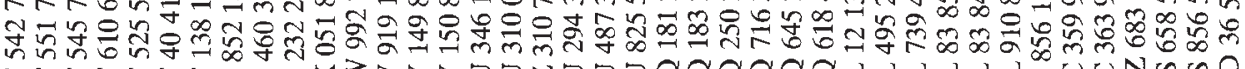

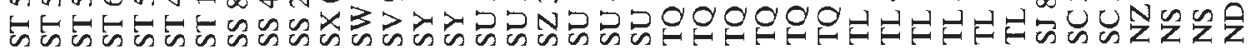

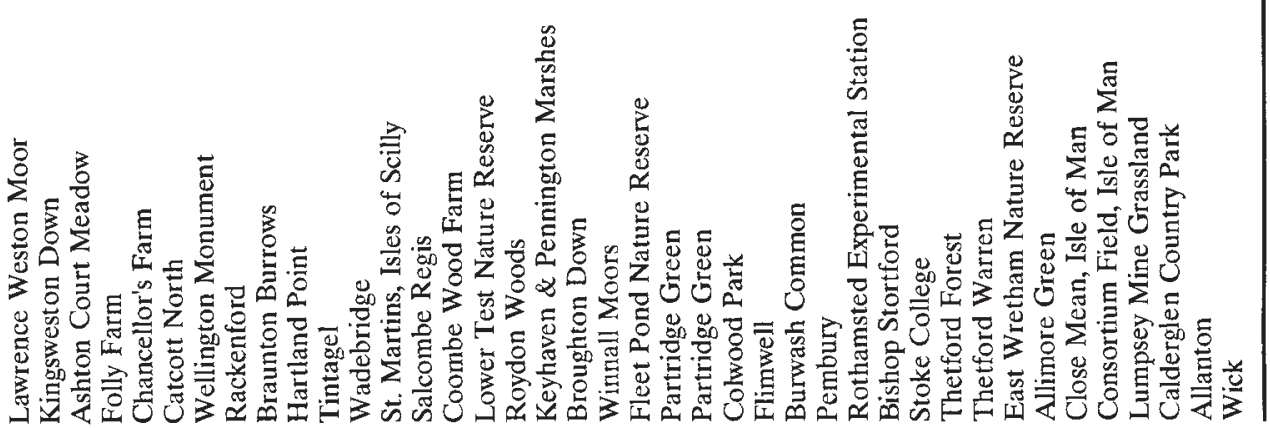


몸

莺

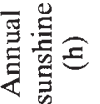

胥

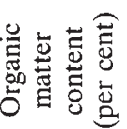

$\Xi$

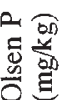

$\bar{\sigma} \frac{00}{80}$

要总

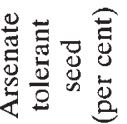

$\ddot{\mathrm{D}}$

?.:

๘)

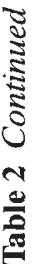

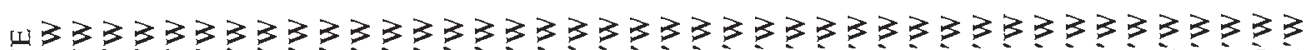

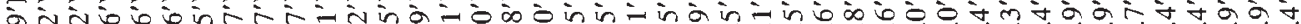
以ु่

zzzzzzzzzzzzzzzzzzzzzzzzzzzzzzzzzzzzzzzzzz त

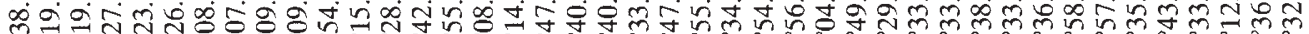

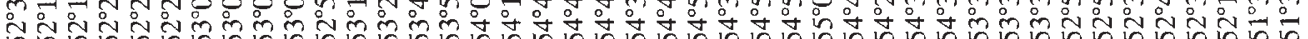

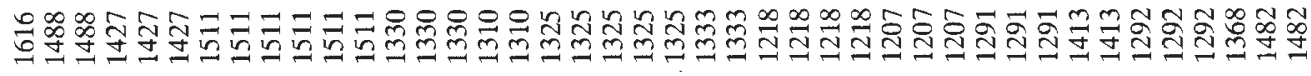

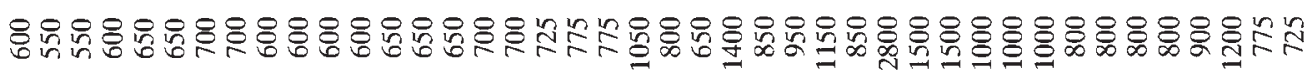

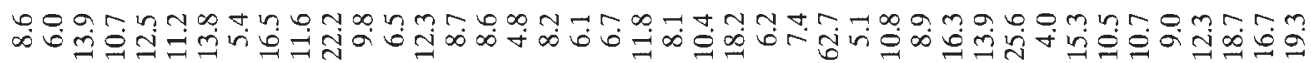

br.

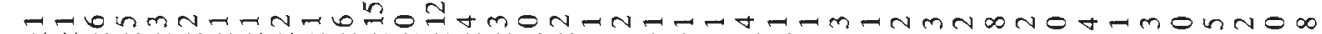
$+1+1+1+1+1+1+1+1+1+1+1+1+1+1+1+1+1+1+1+1+1+1+1+1+1+1+1+1+1+1+1+1+1+1+1+1+1+1+1+1+1+1$

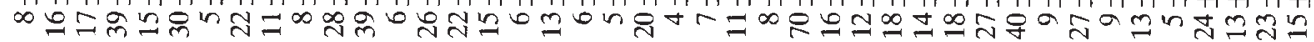

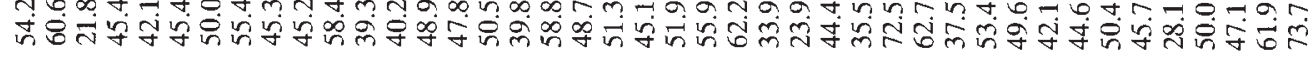

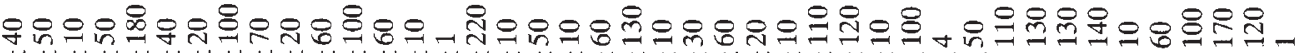
$4+1+1+1+1+1+1+1+1+1+1+1+1+1+1+1+1+1+1+1+1+1+1+1+1+1+1+1+1+1+1+1+1+1+1+1+1+1+1+1+1+1$

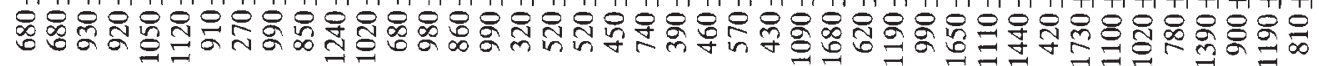

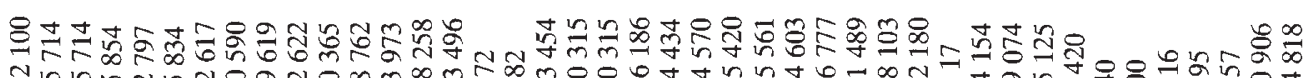

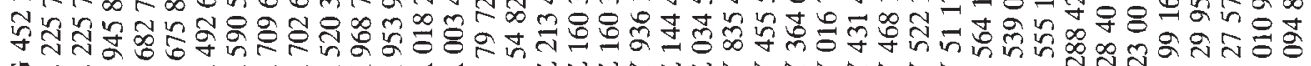

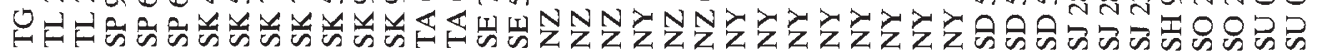

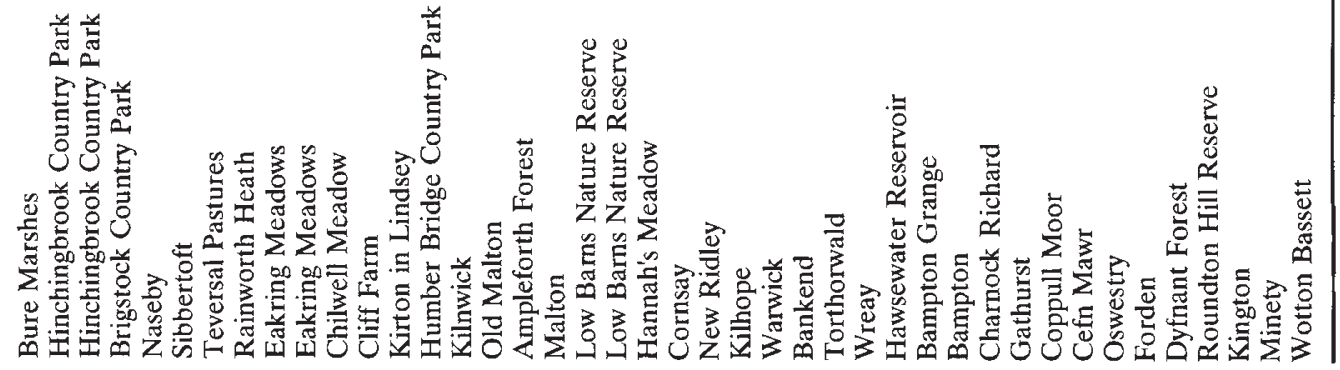

(C) The Genetical Society of Great Britain, Heredity, 77, 509-517. 
Table 3 Correlation coefficients and probabilities for the frequency of arsenate tolerant Holcus lanatus and ecological variables $(\mathrm{NS}=$ non significant $)$

\begin{tabular}{lcc}
\hline Character & $r$ & $P$ \\
\hline Total soil P & 0.058 & $>0.05 \mathrm{NS}$ \\
Olsen P & 0.025 & $>0.05 \mathrm{NS}$ \\
pH & 0.214 & $>0.05 \mathrm{NS}$ \\
Organic matter content & 0.102 & $>0.05 \mathrm{NS}$ \\
Average annual rainfall & 0.206 & $>0.05 \mathrm{NS}$ \\
Average annual sunshine & 0.047 & $>0.05 \mathrm{NS}$ \\
Longitude & 0.107 & $>0.05 \mathrm{NS}$ \\
Latitude & 0.093 & $>0.05 \mathrm{NS}$ \\
\hline
\end{tabular}

\section{Nationwide survey}

Although the frequency of arsenate tolerant genotypes was invariably high on uncontaminated grassland, the attempt to account for the nationwide distribution of the polymorphism by variation in edaphic/environmental factors proved unsuccessful. Arsenic tolerance is undoubtedly a major selective agent on mine sites, with the frequency of tolerant plants on contaminated areas being greater than 90 per cent (Meharg et al., 1993). Throughout the metal tolerance literature the existence of sharp clines on mine boundaries (McNeilly, 1968; Antonovics \& Bradshaw, 1970) and the very low frequency of tolerant plants on noncontaminated sites (Gartside \& McNeilly, 1974; Walley et al., 1974; Symeonidis et al., 1985; Ingram, 1988) provides strong evidence for a 'cost' of metal tolerance. The polymorphism in $H$. lanatus is therefore unusual and suggests either a low cost of arsenate tolerance, or that there are other selective agents operating to maintain a high frequency of tolerant genotypes in every population.

If suppression of the high affinity $P$ uptake system in tolerant plants means they are restricted to areas of high soil phosphorus, then a correlation would be expected between edaphic conditions and the frequency of tolerant genotypes. The hypothesis that tolerant plants might be better adapted to infertile soil should also result in a similar correlation. Yet, neither the results of the work at the Park Grass Experiment nor the nationwide survey give any evidence of a relationship between the frequency of tolerant morphs and soil phosphate status. The explanation may be that uptake kinetics are unimportant in determining the rate of phosphate uptake. Uptake of phosphate occurs via two carrier systems operating in the plasmalemma, both of which obey Michaelis-Menten uptake kinetics (Epstein, 1976).
The low affinity system operates at high substrate concentration, whereas the high affinity system is induced under conditions of phosphate stress (Clarkson et al., 1978; Clarkson \& Lüttge, 1991). Because the concentration of phosphate in soil solution is low (Bieleski, 1973), the high affinity system should be functional under most ecological conditions. However, Nye (1977) found diffusion to be the limiting step in the uptake of poorly soluble nutrients, e.g. phosphate. Because of the binding of $\mathrm{P}$ to soil particles and its low rate of diffusion through the soil, a depletion zone is created around plant roots and further uptake can only occur once $P$ has diffused from the bulk soil into the depletion zone. Silberbush \& Barber (1983) modelled P uptake using a Cushman simulation model involving 11 plant and soil parameters and also concluded that kinetic parameters were relatively unimportant in determining the rate of phosphate uptake. Given that diffusion appears to be the rate-limiting step in the uptake process, increasing the efficiency of ion transport proteins in the plasmalemma, either by increasing $V_{\max }$ (increasing the rate of ion uptake) or reducing $K_{\mathrm{m}}$ (increasing the affinity of the carrier for the substrate) may be fruitless. Intuitively it seems that an individual plant should maximize its ion uptake when nutrients are in short supply. However, studies on Carex spp. (Atwell et al., 1980) and Taraxacum spp. (Hommels et al., 1990) have shown no clear trends between ion uptake capacity and nutrient status of the habitat, a conclusion also reached by Chapin $(1980,1983)$. The fact that genotypes of $H$. lanatus with differing uptake kinetics were found within the same population also gives support to these studies and the role of kinetic parameters remains unclear.

Even if, as might be suggested by these results, phosphate uptake kinetics are unimportant in determining the competitive ability of arsenate tolerant and nontolerant clones, then the existence of the polymorphism is still an enigma. Nontolerant genotypes have a higher $V_{\max }$ (Meharg \& Macnair, 1992b), which has been attributed to the existence of more carrier proteins in the plasmalemma (Drew et $a l ., 1984)$. If uptake kinetics are unimportant, then why do nontolerant plants continue to divert valuable resources into the production of a presumably costly carrier protein? If, on the other hand, the high affinity phosphate system is important then how does such a high frequency of tolerant plants survive in a natural environment? Wilson (1988) proposed that metal tolerance must involve some 'cost' to the plant, reasoning that otherwise the considerable gene flow between tolerant and nontolerant popula- 
tions would cause the tolerance gene to spread through the population and reach a high level, or fixation. The high frequency of arsenate tolerant plants on noncontaminated soils and the lack of evidence for phosphate uptake acting as a selection agent to maintain the polymorphism might lead one to conclude that, in contrast, arsenate tolerance in $H$. lanatus is relatively 'cheap'.

\section{Acknowledgements}

I would like to thank the following Wildlife Trusts for access to sites; Bristol, Bath \& Avon, Buckinghamshire, Durham, Hampshire \& Isle of Wight, Lancashire, Montgomeryshire, Norfolk, Nottinghamshire, Somerset and Wiltshire. Especial thanks to members of the Wildlife Trusts in Cleveland, Dyfed, the Isle of Man, and Scotland, Ian Trueman at the University of Wolverhampton and Fran Harper for their help in sample collection. This research was funded by a NERC grant no. GT4/92/17/L.

\section{References}

ALlen, S. E. 1989. Chemical Analysis of Ecological Materials, 2nd edn. Blackwell Scientific Publications, Oxford.

ANTONOVICS, J. AND BRADSHAW, A. D. 1970. Evolution in closely adjacent plant populations. VII. Clinal patterns at a mine boundary. Heredity, 25, 349-362.

ASHER, C. J. AND REAY, P. F. 1979. Arsenic uptake by barley seedlings. Aust. J. Pl. Physiol., 6, 459-466.

ATWELL, B. J., VEERKAMP, M. T., STUIVER, B. C. E. E. AND Kuiper, P. J. C. 1980. The uptake of phosphate by Carex species from oligotrophic to eutrophic swamp habitats. Physiol. Plant., 49, 487-494.

BIELESKI, R. L. 1973. Phosphate pools, phosphate transport, and phosphate availability. Ann. Rev. Pl. Physiol., 24, 225-252.

BREMNER, J. M. AND JENKINSON, D. S. 1960. Determination of organic carbon in soil. I. Oxidation by dichromate of organic matter in soil and plant materials. J. Soil Sci., 11, 394-402.

CHAPIN, F. S., III. 1980. The mineral nutrition of wild plants. Ann. Rev. Ecol. Syst., 11, 233-260.

CHAPIN, F. S., III. 1983. Adaptation of selected trees and grasses to low availability of phosphorus. Plant and Soil, 72, 283-287.

CLARKSON, D. T. AND LÜTTGE, U. 1991. II. Mineral nutrition: inducible and repressible nutrient transport systems. Progr: Bot., 52, 61-83.

CLARKSON, D. T., SANDERSON, J. AND SCATTTERGOOD, C. B. 1978. Influence of phosphate-stress on phosphate absorption and translocation by various parts of the root system of Hordeum vulgare L. (Barley). Planta, 139, 47-53.

DAVIES, M. S. AND SNAYDON, R. W. 1973a. Physiological differences among populations of Anthoxanthum odoratum L. collected from the Park Grass Experiment, Rothamsted. I. Response to calcium. J. Appl. Ecol., 10, $33-45$.

DAVIES, M. S. AND SNAYDON, R. w. 1973b Physiological differences among populations of Anthoxanthum odoratum L. collected from the Park Grass Experiment, Rothamsted. II. Response to aluminium. J. Appl. Ecol., 10, 47-55.

DAVIES, M. S. AND SNAYDON, R. W. 1974 Physiological differences among populations of Anthoxanthum odoratum L. collected from the Park Grass Experiment, Rothamsted. III. Response to phosphate. J. Appl. Ecol., 11, 699-707.

DAVIES, M. S. AND SNAYDON, R. W. 1976. Rapid population differentiation in a mosaic environment. III. Measures of selection pressures. Heredity, 36, 59-66.

DREW, M. C., SAKER, L. R., BARBER, S. A. AND JENKINS, W. 1984. Changes in the kinetics of phosphate and potassium absorption in nutrient-deficient barley roots measured by a solution depletion technique. Planta, 160, 490-499.

EPSTEIN, E. 1976. Kinetics of ion transport and the carrier concept. In: Lüttge, U. and Pitman, M. G (eds) Transport in Plants 11. Part B, Tissues and Organs, Encyclopaedia of Plant Physiology, pp. 70-94. Springer-Verlag, Berlin.

GARTSIDE, D. W. AND McNEILLY, T. 1974. The potential for evolution of heavy metal tolerance in plants. II. Copper tolerance in normal populations of different plant species. Heredity, 32, 335-348.

HEWITT, E. J. 1966. Sand and Water Culture Methods Used in the Study of Plant Nutrition. Commonwealth Agricultural Bureau, Farnham Royal, Bucks.

HICKEY, D. A. AND McNeILly, T. 1975. Competition between metal tolerant and normal plant populations: a field experiment on normal soil. Evolution, 29, 458-464.

HOMMELS, C. H., SAAT, T. A. W. AND KUIPER, P. J. C. 1990. Characterization of the high-affinity $\mathrm{K}^{+}\left(\mathrm{Rb}^{+}\right)$-uptake system in roots of intact Taraxacum microspecies: comparison of 12 microspecies in relation to their mineral ecology. New Phytol., 114, 695-701.

INGRAM, C. 1988. The Evolutionary Basis of Ecological Amplitude of Plant Species. Ph.D. Thesis, University of Liverpool.

LAWES, J. B. AND GILBERT, J. H. 1880. Agricultural, botanical and chemical results of experiments on the permanent meadow, constructed for more than twenty years in succession on the same land. Part I. The agricultural results. Phil. Trans. $R$. Soc. $(A \& B), 171,289-415$.

LEVINS, R. 1962. Theory of fitness in a heterogeneous environment. I. The fitness set and its adaptive function. Am. Nat., 96, 361-373.

LEVINS, R. 1963. The theory of fitness in a heterogeneous environment. II. Developmental flexibility and niche selection. Am. Nat., 97, 75-90.

MACNAIR, M. R., CUMBES, Q. J. AND MEHARG, A. A. 1992. The genetics of arsenate tolerance in Yorkshire fog, 
Holcus lanatus L. Heredity, 69, 325-335.

MATTINGLY, G. E. G. 1970. Total phosphorus content of soils by perchloric acid digestion and sodium carbonate fusion. J. Agric. Sci. Camb., 74, 79-82.

McNEILly, T. 1968. Evolution in closely adjacent plant populations. III. Agrostis tenuis on a small copper mine, Heredity, 23, 99-108.

MEHARG, A. A. AND MACNAIR, M. R. 1990. An altered phosphate uptake system in arsenate-tolerant Holcus lanatus L. New Phytol., 116, 29-35.

MEHARG, A. A. AND MACNAIR, M. R. 1991. Uptake, accumulation and translocation of arsenate in arsenate-tolerant and non-tolerant Holcus lanatus L. New Phytol., 117, 225-231.

MEHARG, A. A. AND MACNAIR, M. R. 1992a. Genetic correlation between arsenate tolerance and the rate of influx of arsenate and phosphate in Holcus lanatus $\mathrm{L}$. Heredity, 69, 336-341.

MEHARG, A. A. AND MACNAIR, M. R. 1992b. Suppression of the high affinity phosphate uptake system: a mechanism of arsenate tolerance in Holcus lanatus L. J. Exp. Botany, 43, 519-524.

MEHARG, A. A. AND MACNAIR, M. R. 1992c. Polymorphism and physiology of arsenate tolerance in Holcus lanatus L. from an uncontaminated site. Plant and Soil, 146, 219-225.

MEHARG, A. A., CUMBES, Q. J. AND MACNAIR, M. R. 1993. Pre-adaptation of Yorkshire Fog, Holcus lanatus, L. (Poaceae) to arsenate tolerance. Evolution, 47, 313-316.

NYE, P. H. 1977. The rate limiting step in plant nutrient absorption from soil. Soil Sci., 123, 292-297.

OLSEN, S. R., COLE, C. V., WATANABE, F. S. AND DEAN, L. A. 1954. Estimation of available phosphorus in soils by extraction with sodium bicarbonate. United States Department of Agriculture Circular, 939, 19.

SILBERBUSH, M. AND BARBER, S. A. 1983. Sensitivity of simulated phosphorus uptake to parameters used by a mechanistic-mathematical model. Plant and Soil, 74, 93-100.

SNAYDON, R. W. 1970. Rapid population differentiation in a mosaic environment. I. The response of Anthoxanthum odoratum populations to soils. Evolution, 24, $257-269$.
SNAYDON, R. W. AND DAVIES, M. s. 1972. Rapid population differentiation in a mosaic environment. II. Morphological variation in Anthoxanthum odoratum. Evolution, 26, 390-405.

SNAYDON, R. W. AND DAVIES, M. s. 1976. Rapid population differentiation in a mosaic environment. IV. Populations of Anthoxanthum odoratum at sharp boundaries. Heredity, 37, 9-25.

SYMEONDIS, L., MCNEILLY, T. AND BRADSHAW, A. D. 1985. Interpopulation variation in tolerance to cadmium, copper, lead, nickel and zinc in nine populations of Agrostis capillaris L. New Phytol, 101, 317-324.

THURSTON, J. M. 1969. The effects of liming and fertilizers on the botanical composition of permanent grassland, and on the yield of hay. In: Rorison, I (ed.) Ecological Aspects of the Mineral Nutrition of Plants, pp. 3-10. Blackwell Scientific Publications, Oxford.

THURSTON, J. M., WILliams, E. D. AND JOHNSTON, A. E. 1976. Modern developments in an experiment on permanent grassland started in 1856: effects of fertilizers and lime on botanical composition and crop and soil analyses. Annales Agronomiques, 27, 1043-1082.

TILMAN, D., DODD, M. E., SILVERTOWN, J., POULTON, P. R., Johnston, A. E. AND CRAWLEy, M. J. 1994. The Park Grass Experiment: Insights from the most long-term ecological study. In: Leigh, R. A. and Johnston, A. E. (eds) Long-Term Experiments in Agricultural and Ecological Sciences, pp. 287-303, CAB International, Wallingford.

WALLEY, K. A., KHAN, M. S. I. AND BRADSHAW, A. D. 1974. The potential for evolution of heavy metal tolerance in plants. I. Copper and zinc tolerance in Agrostis tenuis. Heredity, 32, 309-319.

WARren, R. G. AND JOHnston, A. E. 1964. The Park Grass Experiment. Rothamsted Experimental Station, Report for 1963, 240-262.

WATT, T. A. 1978. The biology of Holcus lanatus, L. (Yorkshire fog) and its significance in grassland. Herbage Abstr., 48, 192-204.

WEIR, D. A. 1985. The Population Ecology and Clonal Structure of Two Grasses. Ph.D. Thesis, University of Liverpool.

WILsON, J. B. 1988. The cost of heavy-metal tolerance: an example. Evolution, 42, 408-413. 